\title{
Impact Analysis of Coconut Producer Societies in Kerala State
}

\author{
S. U. Aparna ${ }^{1}$ and M. Asokhan ${ }^{2 *}$ \\ ${ }^{1}$ Department of Agricultural Extension and Rural Sociology, Tamil Nadu Agricultural \\ University, Coimbatore, Tamil Nadu, India \\ ${ }^{2}$ (Deputy Registrar, Affiliation), Tamil Nadu Agricultural University, Coimbatore, Tamil \\ Nadu, India \\ *Corresponding author
}

\begin{tabular}{l} 
Key w o r d s \\
$\begin{array}{l}\text { Coconut Producer } \\
\text { Societies, Socio- } \\
\text { economic } \\
\text { upliftment, } \\
\text { Collective } \\
\text { marketing, Impact, } \\
\text { Kerala }\end{array}$ \\
Article Info \\
\hline $\begin{array}{l}\text { Accepted: } \\
\text { 10 March } 2020 \\
\text { Available Online: } \\
\text { 10 April } 2020\end{array}$ \\
\hline
\end{tabular}

A B S T R A C T

Coconut Producer Societies are a non-subsidized knowledge based, farmer centred approach of organizing farmers which aims in socio-economic upliftment through productivity improvement, cost reduction, efficient collective marketing and processing and product diversification. The study was undertaken to analyse the impact of coconut producer societies in Thiruvananthapuram district of Kerala. The data were collected from 130 selected respondents from three villages using proportionate random sampling method through a well-structured and pre-tested interview schedule. It was observed that nearly three-fifth $(59.23 \%)$ of the respondents had medium level of overall perceived impact followed by low $(23.08 \%)$ and high (17.69\%) overall perceived impacts. Initiatives like coconut producer societies will help in organizing the unorganized coconut sector and thus suitable extension strategies has to be implemented for the progress of these societies.

\section{Introduction}

Agriculture, being the backbone of India is unquestionably the largest livelihood provider for the people. In spite of witnessing green revolution, white revolution, yellow revolution and so on Indian agriculture and its allied sectors still faces so many challenges. The largest group of cultivators in Indian agriculture are small and marginal farmers and 85.00 percent of operated holdings are smaller than or about two hectares and amongst these holdings, 66.00 percent are less than one hectare (Singh, 2012).

The small farmers organizations such as cooperatives and FPOs are expected to enhance incomes, reduce costs of input purchases along with transaction costs, create opportunities for involvement in value- 
addition including processing, distribution and marketing, enhance bargaining power and provide access to formal credit (Agarwal, 2010). Thus organizing farmers is a key to overcome so many challenges that farmers are going through.

The Coconut Development Board initiated the formation of Coconut Producer Organizations with an objective of uplifting the socio economic status of the coconut farmers. These organizations have a three tier structure and comprises of Coconut Producer Societies (CPS), Coconut Producer Federations (CPF) and Coconut Producer Companies (CPC) and it ensures maximum participation from the coconut cultivators.

Among these three types of organizations, the Coconut Producer Societies have 40 to 100 farmers who will join collectively and enter into procuring, processing and marketing of coconuts. The Coconut Producer Societies are closely linked with the farmers and they help in greater mobilization of farmers and enhance their production, productivity and profitability. This clearly portrays the importance of Coconut Producer Society and thus an impact analysis of the coconut producer societies on the respondents will help in widening the scope of these societies.

\section{Materials and Methods}

The present study was conducted in Thiruvananthapuram district of Kerala during the year 2019-2020.Among the eleven blocks of the district, three blocks namely Kilimanoor, Athiyannor and Perumkadavila were purposively selected. From these three selected blocks one panchayath each were purposively selected for the study and were Navaikulam from Kilimanoor block, Kanjiramkulam from Athiyannoor block and Perumkadavila from Perumkadavila block. The blocks and panchayaths were selected based on the highest number of coconut producer societies. From the study area, sample sizes of 130 Coconut Producer Society members were selected using proportionate random sampling method.

The data collected on the impact of coconut producer societies were analysed and tabulated using relevant statistical tools. The overall perceived impact of coconut producer societies were studied using the dimensions such as socio personal impact, economic impact, psychological impact, impact on extension participation and impact on postharvest management.

\section{Results and Discussion}

\section{Overall perceived impact of coconut producer societies}

The overall perceived impact of coconut producer society were measured using the dimensions such as socio-personal impact, economic impact, psychological impact, impact on extension participation and impact on post-harvest management .The overall impact of Coconut Producer Society can be achieved through the summation of these dimensions, which was analysed and presented in Table 1.

From Table 1, it is evident that nearly threefifth $(59.23 \%)$ of the respondents had medium level of overall perceived impact of Coconut Producer Society followed by 23.08 per cent of the respondents had low level of overall perceived impact and 17.69 per cent of the respondents had high level of overall perceived impact .

It could be concluded that majority of the respondents had medium to low level of overall impact and the plausible reason for this could be the respondents had received good education, high farming experience, 
better participation in trainings, moderate level of mass media exposure and better group interaction and group cohesiveness. Thus they might experience betterment in their socio personal, economic, psychological, extension participation and post-harvest management aspects.

The above findings are in line with the findings of Ladeiphi (2018).

The dimensions to understand the overall perceived impact of coconut producer society is explained as follows.

\section{Socio-personal impact}

Socio-personal impact analysis helps in understanding the improvement in social and personal characteristics of the respondents. To understand the socio-personal impact, data were collected and presented in Table 2 .

From Table 2, it is clear that just more than half $(58.46 \%)$ of the respondents had medium level of socio personal impact, followed by high and low socio-personal impact with 21.54 per cent and 20.00 per cent respectively. After joining the Coconut Producer Society, trainings and meetings were conducted by the Coconut Development Board and other line departments and this helped them to improve their knowledge, skill and communication aspects. This could be the possible reason for medium to high sociopersonal impact.

The findings are in line with findings of Adsul (2016) and Krishnapriya (2016).

\section{Economic impact}

Economic impact refers to the changes that occurred in the economic condition of the respondents .To study economic impact, data were collected and presented in Table 3. From
Table 3, it is perceived that little less than three-fourth $(73.85 \%)$ of the respondents had medium level of economic impact, followed by 15.38 per cent of the respondents with high economic impact. A negligible (10.77\%) portion of the respondents had low economic impact.

The majority of the respondents had medium to high economic impact and the possible reason for this might be the respondents felt a change in their expenditure, income and purchasing power. The Coconut Producer Society serves as a platform for the respondents to earn an increase in income in terms of production and post-harvest management. The coconut producer societies join together and form Coconut Producer Federation and it further join to form Coconut Producer Company. Also procurement of coconut through Coconut Producer Societies helped the members to get an additional price than the market price.

The findings are in tune with findings of Krishnapriya (2016)

\section{Psychological impact}

The psychological impact helps in understanding the sense of satisfaction and entitlement of the respondents with the coconut producer societies. To study psychological impact, data were collected and presented in Table 4.

From Table 4, it is inferred that a little more than one-third $(38.46 \%)$ of the respondents had high psychological impact, followed by medium (34.62\%) and low (26.92\%) psychological impacts.

The possible reason for this might be the Coconut Producer Society members got better satisfaction and improvement in mind and development after becoming members of 
Coconut Producer Society. Further, the respondents got more exposure and they got motivated and gained confidence. Also the Coconut Producer Society serves as a framework for the members to express their views and clarify their problems in coconut cultivation. The findings are in line with findings of Priyanka (2018)

\section{Impact on extension participation}

Extension participation ensures that the targeted extension approaches and extension services by various extension organizations will reach the farmers and will ultimately benefit them. To understand the impact of Coconut Producer Society on extension participation, data were collected and presented in Table 5. From Table 5, it is revealed that little more than three-fourth (76.16\%) of the respondents had medium impact on extension participation, followed by 13.07 per cent with high and 10.77 per cent of the respondents with low impact on extension participation. This might be due to the greater rapport of Coconut Producer Society members with extension functionaries and Coconut Development Board. Thus they are willing to participate in meetings, trainings and exhibitions. Further the three tier structures of coconut producer organizations enable maximum participation of coconut farmers in various extension activities. The members might also felt that through extension participation they could gain knowledge on modern technologies for coconut cultivation. The findings are parallel with the findings of Neethi (2018)

\section{Impact on post-harvest management}

Post-harvest management is the best solution for meeting the food requirements of the rapid growing population and it helps to reduce the post-harvest losses and offers higher income for the farmers. Data were collected on the impact of Coconut Producer Society on postharvest management and furnished in Table 6. From Table 6 it is concluded that two-third $(66.15 \%)$ of the respondents had medium level impact of Coconut Producer Society on post-harvest management, followed by 18.46 per cent with high impact and 15.39 per cent with low level of impact on post-harvest management.

Table.1 Distribution of respondents according to the overall impact of Coconut Producer Society $(\mathrm{n}=130)$

\begin{tabular}{|l|l|c|c|}
\hline S.No & Category & Number & Per cent \\
\hline 1. & Low & 30 & 23.08 \\
\hline 2. & Medium & 77 & 59.23 \\
\hline 3. & High & 23 & 17.69 \\
\hline & Total & $\mathbf{1 3 0}$ & $\mathbf{1 0 0 . 0 0}$ \\
\hline
\end{tabular}

Table.2 Distribution of respondents according to their socio-personal impact $(n=130)$

\begin{tabular}{|l|l|c|c|}
\hline S.No & Category & Number & Per cent \\
\hline 1. & Low & 26 & 20.00 \\
\hline 2. & Medium & 76 & 58.46 \\
\hline 3. & High & 28 & 21.54 \\
\hline & Total & $\mathbf{1 3 0}$ & $\mathbf{1 0 0 . 0 0}$ \\
\hline
\end{tabular}


Table.3 Distribution of respondents according to their economic impact $(n=130)$

\begin{tabular}{|l|l|c|c|}
\hline S.No & Category & Number & Per cent \\
\hline 1. & Low & 14 & 10.77 \\
\hline 2. & Medium & 96 & 73.85 \\
\hline 3. & High & 20 & 15.38 \\
\hline & Total & $\mathbf{1 3 0}$ & $\mathbf{1 0 0 . 0 0}$ \\
\hline
\end{tabular}

Table.4 Distribution of respondents according to their psychological impact $(n=130)$

\begin{tabular}{|l|l|c|c|}
\hline S.No & Category & Number & Per cent \\
\hline 1. & Low & 35 & 26.92 \\
\hline 2. & Medium & 45 & 34.62 \\
\hline 3. & High & 50 & 38.46 \\
\hline & Total & $\mathbf{1 3 0}$ & $\mathbf{1 0 0 . 0 0}$ \\
\hline
\end{tabular}

Table.5 Distribution of respondents according to the impact of Coconut Producer Society on Extension participation $(n=130)$

\begin{tabular}{|l|l|c|c|}
\hline S.No & Category & Number & Per cent \\
\hline 1. & Low & 14 & 10.77 \\
\hline 2. & Medium & 99 & 76.16 \\
\hline 3. & High & 17 & 13.07 \\
\hline & Total & $\mathbf{1 3 0}$ & $\mathbf{1 0 0 . 0 0}$ \\
\hline
\end{tabular}

Table.6 Distribution of respondents according to the impact of Coconut Producer Society on Post-harvest management $(n=130)$

\begin{tabular}{|c|c|c|c|}
\hline S.No & Category & Number & Per cent \\
\hline 1. & Low & 20 & 15.39 \\
\hline 2. & Medium & 86 & 66.15 \\
\hline 3. & High & 24 & 18.46 \\
\hline & Total & 130 & 100.00 \\
\hline
\end{tabular}

The Coconut Producer Society was established in the year 2012 in Kerala and at that time Neera production was gaining popularity. Thus the trainings on post-harvest management mostly focused on Neera extraction. The possible barriers that still prevent the respondents in practising the postharvest management activities might be the lack of time and insufficient production of coconut. Further there exists a wide scope of utilizing the existing post-harvest technologies fruitfully by the Coconut Producer Society. The findings are in concordance with Rupak (2014).

The paper attempts to study the impact of coconut producer societies as perceived by the respondents in Thiruvananthapuram district of Kerala. The overall impact of coconut producer society was found to be in 
the medium category. The coconut producer societies should sensitize the coconut cultivators regarding the benefits of these societies and thereby the performance of societies can be improved. The study also points out the need for initiatives such as training programmes, financial support from government, pest and disease management in coconut, introduction of coconut parks, strengthening of value addition which will help in the success of coconut producer societies.

\section{References}

Agarwal, B. (2010). Rethinking agricultural production collectivities, Economic and Political weekly, 45(9):64-78.

Jose,T. K. (2014). Coconut producer companies - towards accomplishing goals. Indian Coconut Journal, LVII (3), 4-5.

PrishilaKujur, Aryama Bharati and Urmila Bhagat. 2019. Farmer Producer Organization as an Opportunity to Strengthen Small and Marginal Farmers: A Case study in Rajnandgaon District of Chhattisgarh, India. Int.J.Curr.Microbiol.App.Sci. $\quad$ 8(11): 1832-1838.

Singh, S. (2012) 'New markets for smallholders in India-Exclusion, policy and mechanisms', Economic and Political Weekly, 47: 95-105.

Subhashree Sahu (2014). Socio-Economic Impact of Farmers' Organisation: A Critical Analysis. Published M.Sc (Agri) thesis, Indian Agricultural Research Institute, New Delhi.

\section{How to cite this article:}

Aparna, S. U. and Asokhan, M. 2020. Impact Analysis of Coconut Producer Societies in Kerala State. Int.J.Curr.Microbiol.App.Sci. 9(04): 1201-1206.

doi: https://doi.org/10.20546/ijcmas.2020.904.142 